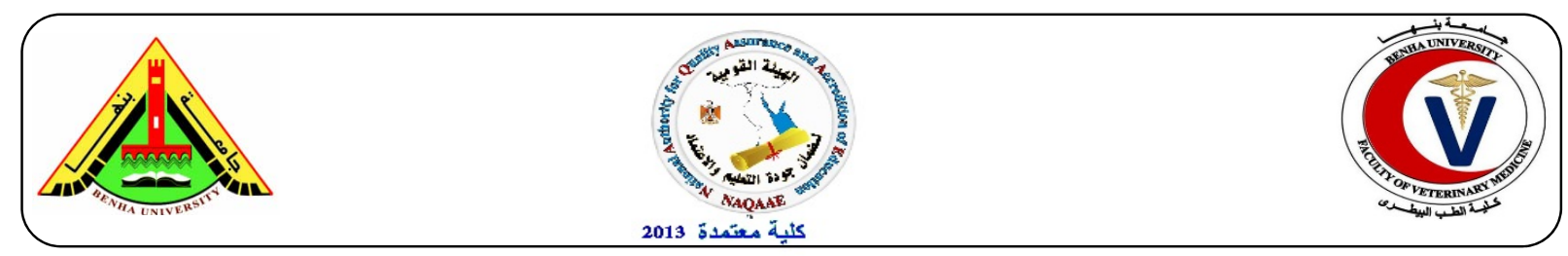

\title{
Molecular characteristics of $E$. coli contaminating from meat products
}

\author{
Emara, N.M.A. ${ }^{2}$, Saad, S.M. ${ }^{1}$ and El-shatter, M.A. ${ }^{2}$ \\ ${ }^{1}$ Food hygiene Department, faculty of veterinary medicine, Benha University \\ ${ }^{2}$ Animal Health Research Institute
}

\begin{abstract}
A B S T R A C T
A total number of 200 meat products samples (50 each of frozen weight of 25 gram of minced meat, frozen beef burger, frozen kofta and traditional Egyptian sausage) were collected from different markets in Cairo and Giza governorates and examined by multiplex polymerase chain reaction method for detecting virulence genes of Escherichia coli strains previously isolated from frozen minced meat, frozen beef burger, frozen kofta and traditional Egyptian sausage. The present study detected the virulence genes stx 1 , st $x 2$, eaeA and hlyA genes among 10 Escherichia coli strains. Results revealed that presence of one or more virulence genes in $E$. coli strains isolated from the examined meat products.
\end{abstract}

KEY WORDS: E. Coli, meat product, PCR, virulence genes.

(http://www.bvmj.bu.edu.eg)

(BVMJ-31(1): 60-63, 2016)

\section{INTRODUCTION}

Culture methods are labor-intensive and timeconsuming while PCR assay based on the sequence of the E. coli gene ensure highly sensitive and specific results (China, et al 1996). Molecular methods detecting virulence genes have been developed to overcome this problem. Most of these methods detect the virulence genes of Escherichia coli (Cebula et al., 1995; Feng and Monday, 2000; Fortin et al., 2001; Gannon et al., 1997; Guion et al., 2008; Oberst et al., 1998; Sharma, 2002; Sharma and Dean-Nystrom, 2003; Yoshitomi et al., 2006). The production of Shiga toxin (Stx) is a characteristic trait of Shiga toxin-producing Escherichia coli (STEC), of which there are several hundred known serotypes, many of which have not been implicated in illness. A subset of STEC, referred to as enterohemorrhagic E. coli (EHEC), is comprised of pathogenic strains and includes serotype O157:H7, a recognized pathogen worldwide, as well as others, such as O26:H11, O111: H8, and O103:H2, that also cause human infections (Karsh et al., 2005).

The aim of this article is to detect the virulence genes in previously isolated E. coli strains from frozen minced meat, frozen beef burger, frozen kofta and traditional Egyptian sausage.

\section{MATERIALS AND METHODS}

\subsection{Materials used for PCR:}

Reagents used for agrarose gel electrophoresis: Agarose powder, Biotechnology grade (Bioshop ${ }^{\mathrm{R}}$, Canda inc. lot No: OE16323). It prepared in concentration 2\% inTAE buffer. Tris acetate EDTA (TAE) electrophoresis buffer (50×liquid concentration) (Bioshop ${ }^{\mathrm{R}}$, Canda inc. lot No: 9E11854). The solution diluted to $1 \times$ by adding 1 $\mathrm{ml}$ stock solution $\mathrm{t} 049 \mathrm{ml}$ double dist. Water to be used in the preparation of the gel or as a running buffer. Ethedium bromide solution (stock solution) biotechnology grade (Bioshop ${ }^{\circledR}$ Canda Inc, Lot No: 0A14667): The stock solution was diluted by $25 \mu 1 / 200 \mathrm{ml}$ double distilled water and stored covered at $4^{\circ} \mathrm{C}$. It was used for staining of PCR products that electrophoreses on agarose gel to be visualized by UV light. Gel loading buffer (6×stock solution) (Fermentas, lot No: ooo56239). The components were dissolved in sterile double distilled water and stored covered with aluminum foil at room temperature. DNA ladder (molecular marker): 100 bp (Fermentas, lot No: 00052518). $5 \mathrm{X}$ Taq master (Fermentas): Containing polymerase enzyme, Magnesium chloride $(\mathrm{Mg}$ C12), Deoxy nucleotide triphosphate (dNTP) and PCR grade water.

\subsection{Primer sequences of $E$. coli used for PCR identification system:}

Application of PCR for identification of shiga toxins (stx1 \& stx2), intimin (eaeA) and 
haemolysin (hylA) genes of E. coli was performed by using primers (Pharmacia Biotech) as shown in the following table 1 .

\subsection{DNA Extraction using QIA amp kit (Shah et al., 2009):}

After overnight culture on nutrient agar plates, one or two colonies were suspended in $20 \mathrm{ml}$ of sterile distilled water, and the suspension was then heated at $100^{\circ} \mathrm{C}$ for 20 minutes. Accurately, $50-200$ $\mu 1$ of the culture were placed in Eppendorf tube and the following steps were carried out: Equal volume from the lysate $(50-200 \mu 1)$ was added, addition of $20-50 \mu \mathrm{l}$ of proteinase $\mathrm{K}$, then incubation at $56{ }^{\circ} \mathrm{C}$ for $20-30 \mathrm{~min}$. After ncubation, $200 \mu \mathrm{l}$ of $100 \%$ ethanol was added to the lysate. The solution was added to the column and centrifuged at $8000 \mathrm{rpm}$ for $1 \mathrm{~min}$. then the filtrate was discarded. The sediment was washed using AW1 buffer $(200 \mu 1)$, the column was centrifuged at $8000 \mathrm{rpm} / 1 \mathrm{~min}$, and the filtrate was discarded. Washing was applied by using the AW2 buffer $(200 \mu 1)$, the column was centrifuged at $8000 \mathrm{rpm} / 1 \mathrm{~min}$. and the filtrate was discarded. The column was placed in a new clean tube then, 25-50 $\mu \mathrm{l}$ from the Elution buffer was added, centrifuged at $8000 \mathrm{rpm} / 1 \mathrm{~min}$. Then the column was discarded. The filtrate was put in clean tube containing the pure genomic DNA Nucleic acid was eluted with $100 \mu$ l of elution buffer provided in the kit.

\subsection{Amplification reaction of E. coli (Fagan et al., 1999):}

The amplification was performed on a Thermal Cycler (Master cycler, Eppendorf, Hamburg, Germany). PCR assays were carried out in $1 \mathrm{ml}$ of nucleic acid template prepared by using reference EHEC isolates (approximately $30 \mathrm{ng}$ of DNA), 10 $\mathrm{mM}$ Tris- $\mathrm{HCl}$ ( $\mathrm{pH}$ 8.4), $10 \mathrm{mM} \mathrm{KCl,} 3 \mathrm{mM} \mathrm{MgCl}$; $2 \mathrm{mM}$ concentrations of each primer, $0.2 \mathrm{mM}$ concentrations of each 29-deoxynucleoside 59triphosphate, and $4 \mathrm{U}$ ofAmpliTaq DNA polymerase (Perkin-Elmer). Amplification conditions consisted of an initial $95^{\circ} \mathrm{C}$ denaturation step for $3 \mathrm{~min}$ followed by 35 cycles of $95^{\circ} \mathrm{C}$ for 20 secs, $58^{\circ} \mathrm{C}$ for $40 \mathrm{~s}$, and $72^{\circ} \mathrm{C}$ for $90 \mathrm{sec}$. The final cycle was followed by $72^{\circ} \mathrm{C}$ incubation for $5 \mathrm{~min}$. The reference strains were E. coli O157:H7 Sakai (positive for stx1, stx2, eaeA and hylA) and E. coli $\mathrm{K} 12 \mathrm{DH} 5 \alpha$ (a nonpathogenic negative control strain) that does not possess any virulence gene (kindly from Prof. Mohamed Hassan, Fac. Vet. Med., Benha Univ.). Amplified DNA fragments were analyzed by $2 \%$ of agarose gel electrophoresis (Applichem, Germany, $\mathrm{GmbH}$ ) in 1x TBE buffer stained with ethidium bromide and captured as well as visualized on UV transilluminator. A 100 bp plus DNA Ladder (Qiagen, Germany, $\mathrm{GmbH}$ ) was used to determine the fragment sizes.

Table (1). Primer sequences of $E$. coli virulence genes:

\begin{tabular}{llll}
\hline Primer & Oligonucleotide sequence $\left(5^{\prime} \rightarrow 3^{\prime}\right)$ & Product size $(\mathrm{bp})$ & References \\
\hline stx1 (F) & 5' ACACTGGATGATCTCAGTGG '3 & & Dhanashree and Mallya (2008) \\
Stx1 (R) & 5' CTGAATCCCCCTCCATTATG '3 & 614 & \\
Stx2 (F) & 5' CCATGACAACGGACAGCAGTT '3 & & \\
Stx2 (R) & 5' CCTGTCAACTGAGCAGCACTTTG '3 & 779 & \\
eaeA (F) & 5' GTGGCGAATACTGGCGAGACT '3 & & Mazahashree and Mallya (2008) \\
eaeA (R) & 5' CCCCATTCTTTTCACCGTCG '3 & 890 & \\
hylA (F) & 5' ACGATGTGGTTTATTCTGGA '3 & & Fratamico et al. (1995) \\
hylA (R) & 5' CTTCACGTGACCATACATAT '3 & 165 & \\
\hline
\end{tabular}

Table (2) Component of PCR Master Mix.

\begin{tabular}{ll}
\hline Component & Volume / Reaction \\
\hline Emerald Amp GT PCR mastermix (2x premix) & $12.5 \mu l$ \\
PCR grade water & $4.5 \mu l$ \\
Forward primer (20 pmol) & $1 \mu l$ \\
Reverse primer (20 pmol) & $1 \mu l$ \\
Template DNA & $6 \mu l$ \\
Total & $25 \mu l$ \\
\hline
\end{tabular}


Table (3) Cycling conditions of the different primers during PCR.

\begin{tabular}{lccccl}
\hline $\begin{array}{l}\text { Target } \\
\text { gene }\end{array}$ & $\begin{array}{c}\text { Primary } \\
\text { denaturation }\end{array}$ & $\begin{array}{c}\text { Secondary } \\
\text { denaturation }\end{array}$ & Annealing & Extension & $\begin{array}{l}\text { Final } \\
\text { extension }\end{array}$ \\
\hline stx1 & $95^{\circ} \mathrm{C}$ & $95^{\circ} \mathrm{C}$ & $58^{\circ} \mathrm{C}$ & $72^{\circ} \mathrm{C}$ & \\
& $3 \mathrm{~min}$. & $20 \mathrm{sec}$. & $20 \mathrm{sec}$. & $1.5 \mathrm{~min}$. & \\
stx2 & $95^{\circ} \mathrm{C}$ & $95^{\circ} \mathrm{C}$ & $58^{\circ} \mathrm{C}$ & $72^{\circ} \mathrm{C}$ & \\
& $3 \mathrm{~min} .$. & $20 \mathrm{sec}$. & $20 \mathrm{sec}$. & $1.5 \mathrm{~min}$. & $72^{\circ} \mathrm{C}$ \\
eaeA & $95^{\circ} \mathrm{C}$ & $95^{\circ} \mathrm{C}$ & $58^{\circ} \mathrm{C}$ & $72^{\circ} \mathrm{C}$ & $5 \mathrm{~min}$. \\
& $3 \mathrm{~min}$. & $20 \mathrm{sec}$. & $20 \mathrm{sec}$. & $1.5 \mathrm{~min}$. & \\
hylA & $95^{\circ} \mathrm{C}$ & $95^{\circ} \mathrm{C}$ & $58^{\circ} \mathrm{C}$ & $72^{\circ} \mathrm{C}$ & \\
& $3 \mathrm{~min}$. & $20 \mathrm{sec}$. & $20 \mathrm{sec}$. & $1.5 \mathrm{~min}$. & \\
\hline
\end{tabular}

\section{RESULTS}

Results from photo (1) the electrophotoretic pattern of $E$. coli by using specific pair primers specific to (stxl) with amplification of 614-bp, stx2 (779bp), eaeA (890bp) and hylA (165bp) genes and table (4) Occurrence of virulence genes of diarrheagenic $E$. coli isolated from the examined meat products, show that O26 Positive strains for stx 1, stx2, eaeA and hly genes, O55 Positive strain for stx 2 and hly genes, O111 Positive strain for stx 1 , eaeA and hly genes, O114): Positive strains for stx 1 \& eaeA genes, O119 Positive strain for stx2 gene, O125 Positive strain for stx1 gene, O125 Positive strain for stx 2 \& eaeA genes and O124 Negative strain for stx 1 , stx 2 , eaeA and hly genes.

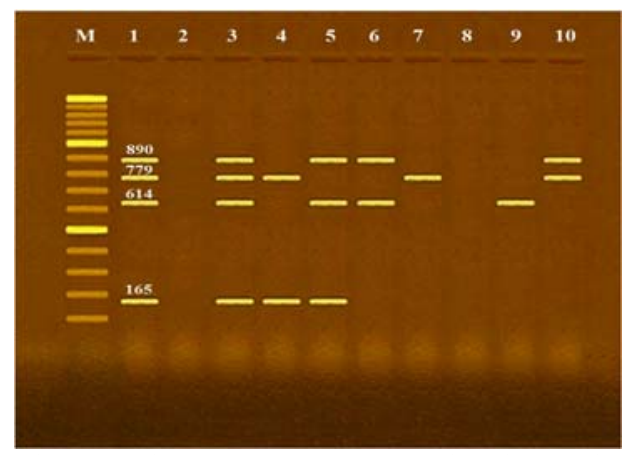

Photograph (1): Agarose gel electrophoresis of multiplex PCR of stx1 (614 bp), stx2 (779 bp), eaeA ( $890 \mathrm{bp}$ ) and hly (165 bp) genes for characterization of Enteropathogenic E. coli. Lane M: 100 bp ladder as molecular size DNA marker. Lane 1: Control positive E. coli for stx1, stx2, eaeA and hly genes. Lane 2: Control negative. Lane 3 (E. coli O26): Positive strains for stx1, stx2, eaeA and hly genes. Lane 4 (E. coli $\mathrm{O} 55)$ : Positive strain for stx 2 and hly genes. Lane 5 (E. coli O111): Positive strain for stx1, eaeA and hly genes. Lanes 6 (E. coli O114): Positive strains for stx 1 \& eaeA genes. Lane 7 (E. coli O119): Positive strain for stx2 gene. Lane 8 (E. coli O124): Negative strain for stx1, stx2, eaeA and hly genes. Lane 9 (E. coli O125): Positive strain for stx1 gene. Lane 10 (E. coli O125): Positive strain for stx $2 \&$ eaeA genes.
Table (4): Occurrence of virulence genes of diarrheagenic $E$. coli isolated from the examined meat products.

\begin{tabular}{lcccc}
\hline E. coli Serovars & Stx 1 & Stx2 & eaeA & hylA \\
\hline O26: H11 & + & + & + & + \\
O55 : H7 & - & + & - & + \\
O111 : H2 & + & - & + & + \\
O114: H21 & + & - & + & - \\
O119: H4 & - & + & - & - \\
O124 & - & - & - & - \\
O125: H21 & + & - & - & - \\
O128: H2 & - & + & + & -
\end{tabular}

Stx1: Shiga- toxin 1 gene, Stx2: Shiga- toxin 2 gene, Eae: intimin gene and hylA: haemolysin gene.

\section{DISCUSSION}

Photo (1) showed the electrophotoretic pattern of $E$. coli by using specific pair primers specific to (stx1) with amplification of 614-bp, stx2 (779bp), eaeA (890bp) and hylA (165bp) genes.

Results obtained from Table (4) revealed that occurrence of one or more virulence genes in $E$. coli strains isolated from the examined meat products. E. coli O26:H11 have the 4 virulence genes, while $\mathrm{O} 124$ have none of the virulence genes. The other strains express one (E. coli O119:H4 and O125:H21) or more virulence genes (O55:H7, O111:H2, O114:H21 and O128:H2). E. coli strains possess that genes were more toxigenic and hazardous to consumer health more than other types which does not contain that gene. The combination of serotyping and stx genotyping was found useful for identification and for assignment of food-borne $E$. coli to groups with potential lower and higher levels of virulence for humans (Beutin, et al 2007). Similar results were obtained by Helmy (2003), Beutin, et al (2007) and Pradel, et al (2008). 
The major characteristic of $E$. coli linked to virulence is the production of one or more virulence genes (Stx1, Stx2, eaeA and hylA) Toxin and adherence factors may be necessary to cause disease (Tizpori, 1987 and Paton and Paton, 1998). Culture methods are labor-intensive and timeconsuming while PCR assay based on the sequence of the E. coli gene ensure highly sensitive and specific results (China, et al 1996).

The DNA sequences of the genes in the Oantigen gene clusters can be utilized to design PCR based assays for the detection or identification of specific E. coli serogroups. PCR assays were developed to detect or identify E. coli on the basis of the virulence genes. The use of the PCR assays provides the ability to detect, identify, and type this serogroup, eliminating the use of the more laborintensive serotyping procedure. (Pradel, et al.,2008).

\section{REFRENCES}

Beutin L., Miko A., Krause G., Pries K., Haby S. and Steege K. 2007. Identification of humanpathogenic strains of Shiga toxinproducing Escherichia coli from food by a combination of serotyping and molecular typing of Shiga toxin genes. Appl. Environ. Microbiol. 73, 4769-4775

Caprioli A, Luzzi I, Gianviti A, Russmann H, Karch H. 1995. Phenogenotyping of verotoxin 2 (VT2)producing Escherichia coli causing haemorrhagic colitis and haemolytic uraemic syndrome by direct analysis of patients' stools. J Med Microbiol 43:48-353.

China, B. Pirson, V. and Mainil, J. 1996. Typing of bovine attaching and effacing E.coli by multiplex in vitro amplification of virulence-associated genes. Appl. Environ. Microbiol. 62:3462.

Dhanashree, B. and Mallya, P. S. 2008. Detection of shiga-toxigenic Escherichia coli (STEC) in diarrhoeagenic stool \& meat samples in Mangalore, India. Indian J Med Res 128:271277.

Fagan, P.; Hornitzky, M.; Bettelheim, K. and Djordjevic, S. 1999. Detection of Shiga-Like Toxin (stx1 and stx2), Intimin (eaeA), and Enterohemorrhagic E. coli (EHEC) Hemolysin (EHEC hlyA) genes in animal feces by multiplex PCR. Appl. Environ. Microbiol., 65(2): 868-872.

Feng P, Monday SR. 2000. Multiplex PCR for detection of trait and virulence factors in enterohemorrhagic Escherichia coli serotypes. Mol Cell Probes 14:333-337.

Fortin NY, Mulchandani A, Chen W. 2001. Use of realtime polymerase chain reaction and molecular beacons for the detection of Escherichia coli O157:H7. Anal Biochem 289:281-288.
Fratamico, P.; Sackitey, S.; Wiedmann, M. and Deng, M. 1995. Detection of Escherichia coli O157:H7 by multiplex PCR. J. Clin. Microbiol. 33: 21882191.

Gannon VP, D'Souza S, Graham T, King RK, Rahn K, Read S. 1997. Use of the flagellar H7 gene as a target in multiplex PCR assays and improved specificity in identification of enterohemorrhagic Escherichia coli strains. J Clin Microbiol 35:656-662.

Guion CE, Ochoa TJ, Walker CM, Barletta F, Cleary TG. 2008. Detection of diarrheagenic Escherichia coli by use of melting-curve analysis and real-time multiplex PCR. J Clin Microbiol 46:1752-1757.

Karch, H., P. I. Tarr, and M. Bielaszewska. 2005. Enterohaemorrhagic Escherichia coli in human medicine. Int. J. Med. Microbiol. 295:405-418.

Mazaheri, S.; Ahrabi, S. and Aslani, M. 2014. Shiga Toxin-Producing Escherichia Coli Isolated from Lettuce Samples in Tehran, Iran. Jundishapur J. Microbiol., 7 (11): 1-6.

Oberst RD, Hays MP, Bohra LK, Phebus RK, Yamashiro CT, Paszko-Kolva C, Flood SJ, Sargeant JM, Gillespie JR. 1998. PCR-based DNA amplification and presumptive detection of Escherichia coli O157:H7 with an internal fluorogenic probe and the 5' nuclease (TaqMan) assay. Appl Environ Microbiol 64:3389-3396.

Paton J. C. and Paton A. W. 1998. Pathogenesis and diagnosis of Shiga toxin-producing Escherichia coli infections. Clin. Microbiol. Rev. 11450 479.

Pradel N., Bertin Y., Martin C. and Livrelli V. 2008. Molecular analysis of shiga toxinproducing Escherichia coli strains isolated from hemolytic-uremic syndrome patients and dairy samples in France. Appl. Environ. Microbiol. 74 2118-2128 10.1128/AEM.02688

Shah, D., Shringi, S., Besser, T. and Call, D. 2009. Molecular detection

of foodborne pathogens, Boca Raton: CRC Press, In Liu, D. (Ed). Taylor \& Francis group, Florida, USA, Pp. 369-389.

Sharma VK. 2002. Detection and quantitation of enterohemorrhagic Escherichia coli O157, $O 111$, and 026 in beef and bovine feces by realtime polymerase chain reaction. J Food Prot 65:1371-1380.

Sharma VK, Dean-Nystrom EA. 2003. Detection of enterohemorrhagic Escherichia coli O157:H7 by using a multiplex real-time PCR assay for genes encoding intimin and Shiga toxins. Vet Microbiol 93: 247-260.

Yoshitomi KJ, Jinneman KC, Weagant SD. 2006. Detection of Shiga toxin genes stx 1, stx2, and the +93 uidA mutation of E. coli O157:H7 using SYBR Green I in a real-time multiplex PCR. Mol Cell Probes 20: 31-41. 